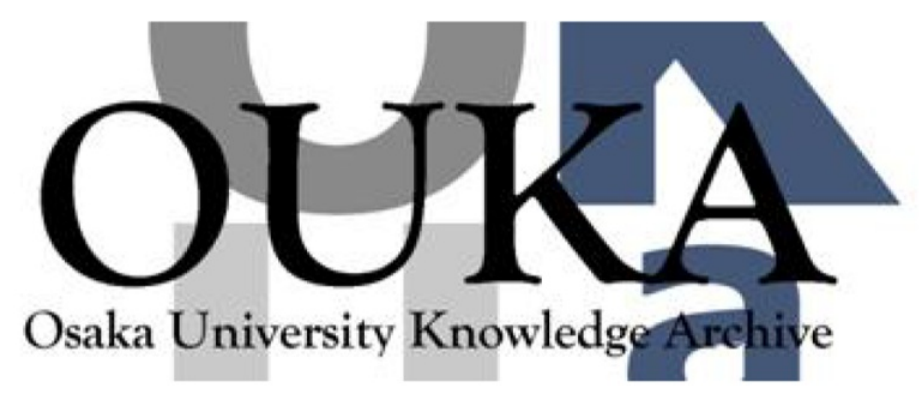

\begin{tabular}{|c|l|}
\hline Title & $\begin{array}{l}\text { The Kennedy Administration and Project Apollo : } \\
\text { International Competition and Cooperation } \\
\text { through Space Policy }\end{array}$ \\
\hline Author(s) & Watanabe, Hirotaka \\
\hline Citation & 0saka University Law Review. 56 p. 31-p. 48 \\
\hline Issue Date & $2009-02$ \\
\hline oaire:version & VoR \\
\hline URL & https://hdl. handle. net/11094/9916 \\
\hline rights & \\
\hline Note & \\
\hline
\end{tabular}

Osaka University Knowledge Archive : OUKA

https://ir. Library. osaka-u. ac. jp/

Osaka University 


\title{
The Kennedy Administration and Project Apollo: International Competition and Cooperation through Space Policy*
}

\author{
Hirotaka WATANABE ${ }^{\dagger}$
}

\begin{abstract}
The Kennedy administration decided on and carried out Project Apollo to defeat the Soviet Union in the moon race, while it also strived to realize U.S.-Soviet joint human lunar exploration in addition to their negotiations about space science cooperation. This article examines the change of the two aspects of Project Apollo, competition and cooperation with the Soviet Union, during one thousand days of the Kennedy administration from the perspective of U.S. foreign policy in the Cold War. The Kennedy administration chose Project Apollo as a crucial national policy that would bear part of the U.S. foreign policy, and advanced it by laying emphasis on competition or cooperation in accordance with the change of U.S.-Soviet relations. The purpose of Project Apollo was not only the display of U.S. power and ideas but also the relaxation of the tensions in the Cold War. The space policy of the Kennedy administration, with Project Apollo as the central program, restored gradually the U.S. international status of those days, and contributed to the opening of the peaceful coexistence in the 1960 s with other foreign policies of the administration.
\end{abstract}

\section{Introduction}

It has been about forty years since Americans first landed on the surface of the moon. Surprisingly enough, this first lunar landing might have been accomplished as a U.S.-Soviet joint project. It is true that the Kennedy administration decided to go to the moon so as to defeat the Soviet Union in the next space race just after the Soviet first human spaceflight. However, the Kennedy administration also strived to realize U.S.-Soviet joint human lunar exploration, advocating international cooperation in space activities. The concrete plan for cooperation was about to be

* This article is the revised version of the paper with the same title (IAC-06-E4.2.01), presented at the 57th International Astronautical Congress (IAC), Valencia, Spain, 2-6 October 2006.

$\dagger$ Research Fellow, Graduate School of Law and Politics, Osaka University, Japan.

E-mail: hirotaka@law.osaka-u.ac.jp 
brought up to the Soviet Union when President Kennedy was assassinated in November 1963.

The two aspects of Project Apollo, competition and cooperation with the Soviet Union, have been examined by making use of the materials declassified especially after the end of the Cold War. ${ }^{1)}$ But it has not yet been fully explained how and why the two aspects had changed during one thousand days of the Kennedy administration. Besides, some important documents about the top-level space policy decisions of those days have been unveiled in recent years.

With the awareness of the issues, this article examines historically how the Kennedy administration decided on and carried out Project Apollo in the Cold War, paying attention to the relationship between the space policy and the foreign policy of the Kennedy administration.

First, this article considers why John F. Kennedy explored a cooperationoriented space policy in the first months of his administration, although he had asserted in the presidential election that the United States should win space competition with the Soviet Union. Next, it reviews why the Kennedy administration decided to go to the moon in April-May 1961. Then, it examines why Kennedy proposed U.S.-Soviet joint lunar exploration both in the Vienna summit meeting of June 1961 and in the United Nations (UN) General Assembly of September 1963, while the administration was putting forth serious efforts to implement Project Apollo. Finally, this article summarizes the transition of the two aspects of Project Apollo and discusses the purpose and meaning of Project Apollo as the space policy of the Kennedy administration in the Cold War.

\section{The Birth of the Kennedy Administration}

The origin of the space policy of the Kennedy administration can be traced back to the "Sputnik shock" in the fall of 1957. Two Democratic Senators severely blamed the then Eisenhower Republican administration for causing the shock, though many Senators and others did the same thing more or less. Those were John F. Kennedy and Lyndon B. Johnson.

The Soviet Union succeeded in the launch of the first artificial satellite Sputnik 1 on 4 October 1957, following the first inter-continental ballistic missile (ICBM) in August of the same year. It was a great shock to people in western countries who believed the U.S. superiority over the Soviet Union. In the United States, this shock led to the disputes over the twin gaps, the "missile gap" in nuclear capability and the "space gap" in space science and technology. ${ }^{2)}$

But the Eisenhower administration didn't immediately respond to the shock. 
Johnson, as majority leader and chairman of the preparedness subcommittee of the Senate Armed Services Committee, called for a raise in the budget for space and missiles. As the Democratic Party held a majority in both Houses of Congress, the Eisenhower administration accelerated some ballistic missile programs and established the National Aeronautics and Space Administration (NASA) and the National Aeronautics and Space Council (NASC) in the fall of 1958.

On the other hand, Kennedy, as a member of the Foreign Relations Committee, advocated overcoming the two gaps from the standpoint of U.S. foreign policy. In August 1958, Kennedy stated a grave situation of the missile gap, and took up the "Sputnik diplomacy" as one of the threats to the United States in the following speech before the Senate:

"The most critical years of the [missile] gap would appear to be 1960-1964... Their missile power will be the shield from behind which they will slowly, but surely, advance-through [S]putnik diplomacy, limited brushfire wars, indirect nonviolent aggression, intimidation and subversion, internal revolution, increased prestige or influence, and the vicious blackmail of our allies."3)

The Sputnik diplomacy was a propaganda campaign that Soviet Premier Nikita S. Khrushchev had been carrying on to make people all over the world believe that the military, economic and national power of the Soviet Union would be superior to that of the United States, through the Soviet space achievements like Sputnik. Kennedy felt keenly the necessity of taking countermeasures against Khrushchev's space diplomacy.

Kennedy and Johnson, who became famous through the disputes over the two gaps, were nominated for presidential candidate and vice presidential candidate, respectively, in the Democratic national convention of July 1960. Kennedy set out the "New Frontier" policy for the buildup of national power and the progress of society, in order to confront Richard M. Nixon, the Republican presidential candidate. While Nixon insisted the achievements of Eisenhower's space policy, especially in the field of science and practical use, Kennedy asserted that "We are in strategic space race with the Russians, and we are losing.... But we cannot run second in this vital race." 4 )

Finally in the 1960 campaign, Kennedy's assertion that the United States should close the gap and win space race with the Soviet Union seemed to be more convincing than Nixon's affirmation of the status quo. Kennedy beat Nixon by the slim margin in the presidential election, and would be inaugurated as the 35 th President of the United States. 
The president-elect Kennedy asked Jerome B. Wiesner, Professor of the Massachusetts Institute of Technology, to investigate the present U.S. space activities. On 10 January 1961, Wiesner submitted to Kennedy the "Report to the President-Elect of the Ad Hoc Committee on Space."5) It emphasized national prestige, national security, and international cooperation as the principal motivations of space program, and concluded that "a crash program aimed at placing a man into an orbit at the earliest possible time cannot be justified solely on scientific or technical grounds." As Kennedy and Johnson hoped for a new space program which would be different from Eisenhower's, the report did not necessarily meet their expectation. ${ }^{6}$ ) But Kennedy appointed him the Special Assistant to the President and chairman of the President's Science Advisory Committee (PSAC) because Kennedy trusted him and the technical value of his report.

Kennedy also reformed the National Aeronautics and Space Council (NASC) more functionally by designating Vice President Johnson as its chairman. But it was in April 1961 when Johnson was formally appointed as chairman of NASC. Moreover, it was in February 1961 when James B. Webb was appointed as new NASA Administrator. Only Wiesner took office formally at the birth of the Kennedy administration. In addition, Kennedy had seen space as an area for international cooperation, as well as competition, even during the presidential campaign. ${ }^{7}$ Thus, the space policy of the Kennedy administration started in line with Wiesner's view, the promotion of international cooperation in space activities.

In the inaugural address and the State of the Union Message of late January 1961, President Kennedy stated that the United States was ready to cooperate with other countries, including the Soviet Union, in the field of weather prediction, satellite communications, and planetary exploration. ${ }^{8)}$ He added that "both nations [the United States and the Soviet Union] would help themselves as well as other nations by removing these endeavors from the bitter and wasteful competition of the Cold War." Kennedy thought that the United States should advance international cooperation in space activities while building up its power of space science and technology.

Kennedy directed Wiesner to draw up the concrete plan for space cooperation, and also started direct exchanges of opinions with Khrushchev about space cooperation. Khrushchev replied to Kennedy that favorable conditions for space cooperation "would be created through the settlement of the problem of disarmament."9) Kennedy discussed the response with Wiesner. In his memorandum to Kennedy, Wiesner recommended that the United States should 
advance such space programs not as to stimulate the space competition with the Soviet Union but as to promote international space cooperation, display the richness of the United States to international society, and ease international tensions. ${ }^{10)}$ This was the main point of Wiesner's cooperative-oriented space policy, and also the first space policy of the Kennedy administration.

At the meeting about the NASA supplementary budget on 22-23 March 1961, the Kennedy administration decided to accelerate the large booster program, Project Saturn, and not to start an advanced human spaceflight program, Project Apollo, for the following two reasons. ${ }^{11)}$ First, as the first human spaceflight of Project Mercury was slated for the next month, Kennedy and his space advisors wanted to make a judgment after the flight. Second, the Kennedy administration was under the pressure to deal with the problems in the third world at that time. The East-West tensions were running high in Congo, Laos, and Cuba. Therefore it was conceivable that the space policy of the Kennedy administration bore its role of easing the tensions by pursuing international cooperation.

Thus the Kennedy administration started the space policy for not only strengthening of the U.S. space science and technology power but also promoting international cooperation. It was rather far from Kennedy's remarks on the space race with the Soviet Union in the 1960 presidential election.

\section{The Decision to Go to the Moon ${ }^{12)}$}

In early April 1961, Kennedy was told that the Soviet Union might carry on the first human spaceflight soon. But the Kennedy administration had little sense of competition with the Soviet Union in realizing the first human spaceflight, like the Eisenhower administration in launching the first satellite. As expected, the Soviet Union succeeded in putting Yuri A. Gagarin aboard Vostok 1 into the Earth orbit on 12 April 1961. Khrushchev propagandized extensively the achievement, as he had done following Sputnik 1, as the evidence of the further development of the Soviet socialism. The Kennedy administration tasted defeat, as the Eisenhower administration did, in the psychological and political space competition with the Soviet Union, although the United States was not behind in the purely scientific space competition. To the United States, this became the "Gagarin shock" following the "Sputnik shock."

Nevertheless, Kennedy and NASA took careful response to the shock, although the administration recognized that the United States should accelerate or change its space programs and began to consider some kinds of human lunar exploration. Kennedy thought that he wouldn't be made to bear the responsibility because only 
three months had passed since the start of the Kennedy administration. On the other hand, NASA was steadily preparing for the U.S. first human spaceflight. Immediately after the Gagarin shock, however, another shock attacked the Kennedy administration.

The Kennedy administration had been tackling the third world policy since the start. In January 1959, the revolution led by Fidel Castro broke out in Cuba and the Castro administration was born. The Eisenhower administration ordered the Central Intelligence Agency (CIA) to draw up the plan to overthrow the Castro administration, which strengthened its dependence on the Soviet Union. When the preparation was completed, the U.S. government changed to Kennedy from Eisenhower. While Allen W. Dulles, Director of CIA, pressed Kennedy to order to begin the operations, Arthur M. Schlesinger, Jr., Special Assistant to the President, and Democratic Senator J. William Fulbright firmly opposed them.

After all, Kennedy took a compromise plan to execute the operations not under the name of the United States. Cuban refugees given military training in the United States started to invade the Bay of Pigs in Cuba on 15 April 1961, three days after Gagarin's flight. But the invasion ended soon in complete failure because the Castro administration had made thoroughgoing preparations for it. To the Kennedy administration, this failure became the "Bay of Pigs shock," following the Gagarin shock.

Did the Bay of Pigs shock influence the formulation of a new space program, Project Apollo? It seemed to be "never explicitly linked to the acceleration of the space program." "13) But McGeorge Bundy, Special Assistant to the President, says that "it is quite possible, if the Bay of Pigs had been a resounding success, the President might have dawdled a little longer on the space decision."14) Schlesinger also writes that the President tried "to divert the demand of action against Castro into a general strengthening of American purpose."15)

Therefore, it should be stated that the Bay of Pigs shock hastened the decision on a new space program, and made it bear more part of the U.S. foreign policy that could build a new peaceful framework in the Cold War. The Kennedy administration started to formulate a new space program in order to overcome dramatically both the "Gagarin shock" and the "Bay of Pigs shock."

Kennedy first ordered Johnson to investigate the present U.S. space activities and propose a new space program to beat the Soviet Union, when Johnson was formally appointed as chairman of NASC on 20 April 1961. While he was drawing together various opinions within the government, Congress, and communities of space specialists by his own personal network, Johnson held two large meetings to 
discuss a new space program. ${ }^{16)}$ One was for the discussion about its technological possibility with NASA, the Department of Defense (DOD), and the Bureau of the Budget (BOB) on 24 April. The other was for the discussion about its political possibility with Congressmen on 3 May. Through these meetings, Johnson mostly completed the consensus-building to decide on a new space program, which would realize the first human lunar landing.

On 5 May, Alan B. Shepard, Jr. succeeded in the first U.S. human suborbital flight aboard the Mercury spacecraft Freedom 7. The flight swept away uneasiness and doubt over the human spaceflight programs in the United States. On 8 May, NASA Administrator Webb and Robert S. McNamara, Secretary of Defense, submitted to Kennedy the report, "Recommendations for Our National Space Program: Changes, Policies, Goals." It stated that:

"This nation needs to make a positive decision to pursue space projects aimed at enhancing national prestige. Our attainments are a major element in the international competition between the Soviet system and our own. The non-military, non-commercial, nonscientific but 'civilian' projects such as lunar and planetary exploration are, in this sense, part of the battle along the fluid front of the cold war."17)

Kennedy held a meeting to examine the recommendations on 10 May. There the Kennedy administration finally decided on Project Apollo which would realize the first human lunar landing during the 1960 s. ${ }^{18}$ )

In parallel with the deliberation of Project Apollo, the Kennedy administration was pressed to make a decision whether Kennedy should hold the first summit meeting with Khrushchev on that occasion. Originally in late February 1961, Kennedy proposed it to Khrushchev, and Khrushchev agreed to it in late April, after the two shocks. Robert F. Kennedy, Attorney General, coordinated the agenda of the summit in back channel with Georgi Bolshakov, an intelligent attaché of the Soviet Embassy in Washington. ${ }^{19)}$ On 16 May, Kennedy received not only an acceptance letter from Khrushchev about the summit in Vienna, but also the report of the U.S.-Soviet space cooperation plan from Wiesner. ${ }^{20)}$ Although the report had been finished in April, Wiesner had no chance to submit it to Kennedy because of the two shocks. Kennedy himself could not figure out how Project Apollo should be announced in view of its vast cost and influence on the U.S.-Soviet relations. Thus, he decided to search for the best way by sounding out the possibility of the U.S.Soviet space cooperation including Project Apollo. ${ }^{21)}$

Kennedy directed Robert Kennedy and Dean Rusk, Secretary of States, to 
propose U.S.-Soviet space cooperation to the Soviet Union. Rusk talked with Andrei A Gromyko, Soviet Foreign Minister, on 20 May, and Robert Kennedy met Bolshakov on 21, 23, and 24 May. But in the preparatory negotiations, Kennedy reached a conclusion that the Soviet Union had no intention to create any agreement on the issues, including space cooperation, and underestimated the intention and power of the United States. Kennedy made up his mind to announce Project Apollo as a new national policy to clearly demonstrate the U.S. confrontational stance to the Soviet Union in the Cold War.

On 25 May 1961, Kennedy proposed Project Apollo in the following speech titled the "Urgent National Needs" as the second State of the Union Message:

"I believe that this Nation should commit itself to achieving the goal, before this decade is out, of landing a man on the moon and returning him safely to earth.... But in a very real sense, it will not be one man going to the moon-it will be an entire nation. For all of us must work to put him there."22)

Although the United States only succeeded in the first suborbital flight, the announcement of Project Apollo gave a great surprise to American people as well as all over the world. Thanks to Johnson's consensus-building, the proposal and the additional funding needed to get started were passed by an overwhelming majority in both Houses of Congress. By Kennedy's speech and their swift passing, Kennedy could impress strongly his leadership on the U.S. domestic society, and the Kennedy administration could take the first step to recover the international status of the United States.

Thus the two shocks, Gagarin and the Bay of Pigs, made the Kennedy administration to completely reverse its space policy for international cooperation. Still in fact, the Kennedy administration also continued to search a way to cooperate the Soviet Union in space activities, including Project Apollo.

\section{The Evolution of U.S.-Soviet Space Cooperation}

Kennedy left for Vienna to meet Khrushchev right after the announcement of Project Apollo. The main subjects of the U.S.-Soviet summit meeting were Berlin, Laos, and nuclear test ban problems. But in the tense discussions, Kennedy proposed the U.S.-Soviet joint lunar program on the first day of the summit, 3 June 1961. Khrushchev accepted it once, but on the next day he declined it because of disarmament problems. ${ }^{23}$ )

Yet Kennedy felt that Khrushchev wasn't so stimulated by the announcement of Project Apollo, and also found a political and diplomatic value in pursuing the 
realization of the U.S.-Soviet space cooperation. Before the summit, Kennedy had been concerned that Project Apollo would make the U.S.-Soviet space competition too intense and also the U.S.-Soviet relations worse. That was why Kennedy proposed the joint lunar program. After that, Kennedy advanced Project Apollo to beat the Soviet Union, but at the same time he sought out international space cooperation to make better U.S.-Soviet relations.

At the 16th UN General Assembly of 25 September 1961, Kennedy proposed "reserving outer space for peaceful use, prohibiting weapons of mass destruction in space or on celestial bodies, and opening the mysteries and benefits of space to every nation," by referring to international space cooperation in weather prediction and communications satellites. ${ }^{24)}$ It led to the UN General Assembly Resolution 1721 (XVI), "International Cooperation in Peaceful Use of Outer Space," because the Soviet Union joined the meetings of the Committee on the Peaceful Uses of Outer Space (COPUOS) for the first time. ${ }^{25)}$ This meant that the Soviet Union might discuss international space cooperation with the United States, independently of disarmament problems.

On 21 February 1962, John H. Glenn succeeded in the first U.S. orbital flight aboard the Mercury spacecraft Friendship 7. Khrushchev sent to Kennedy a message of congratulations that:

"If our countries pooled their efforts-scientific, technical and material - to master the universe, this would be very beneficial for the advance of science and would be joyful acclaimed by all peoples who would like to see scientific achievements benefit man and not be used for "cold war' purposes and the arms race."26)

Judging this message to be a good opportunity to realize space cooperation, Kennedy replied that:

"I welcome your statement that our countries should cooperate in the exploration of space. I have long held this same belief and indeed put it forward strongly in my first State of the Union message.... I am instructing the appropriate officers of this Government to prepare new and concrete proposals for immediate projects of common action, and I hope that at a very early date our representatives may meet to discuss our ideas and yours in a spirit of practical cooperation."27)

Thus the bilateral talks concerning space cooperation started, and they reached the preliminary agreement on the cooperation in the field of meteorological satellites, communications satellites and geomagnetic research on 8 June $1962 .{ }^{28)}$ 
The negotiations continued even in the middle of the Cuban missile crisis and they worked out a final agreement in August 1963. Furthermore, they led to the possibility of the U.S.-Soviet joint lunar program.

On the other hand, Kennedy continued to insist that the United States should carry through Project Apollo to be the world leader. He made the following speech at Rice University in Houston, Texas on 12 September 1962:

"The exploration of space will go ahead, whether we join in it or not, and it is one of the great adventures of all time, and no nation which expects to be the leader of other nations can expect to stay behind in this race for space.... We choose to go to the moon. We choose to go to the moon in this decade and do the other things, not because they are easy, but because they are hard, . . ",29)

Right after this speech, the Cuban missile crisis of October 1962 had two contradictory effects on the space policy of the Kennedy administration. ${ }^{30)}$ First, it made Kennedy recognize again the importance of the U.S. space science and technology power. At the meeting of 21 November, just after the Cuban crisis, NASA Administrator Webb asserted that the United States "might not have been as successful on Cuba if we hadn't flown John Glenn and demonstrated we had a real overall technical capability here."31) Kennedy answered that "We agree. That's why we wanna put this program [Project Apollo].... That's the dramatic evidence that we're preeminent in space." ${ }^{32}$ ) The Cuban crisis strengthened Kennedy's conviction that the United States should implement Project Apollo, which the "highest (DX) national priority" was assigned to in the spring of 1962, to develop U.S. space power. ${ }^{33)}$

But the Cuban crisis also made Kennedy feel acutely the need for the easing of the East-West tensions. To improve the U.S.-Soviet relations, the Kennedy administration continued the negotiations on space science cooperation with the Soviet Union. After the Cuban crisis, the Kennedy administration pursued further both space competition, by Project Apollo, and space cooperation, by space science, with the Soviet Union.

Something serious to Project Apollo happened in July 1963. British astronomer Sir Bernard Lovell, who came back from a trip to Soviet space facilities, reported that the Soviet Union had no human lunar landing program, and rather was willing to cooperate with the United States and other countries in moon exploration. ${ }^{34)}$ Kennedy seemed to be upset about the information, and he couldn't make a decision immediately though he had proposed the U.S.-Soviet joint lunar project before. $^{35)}$ 
As international tensions had eased after the Cuban crisis, the Limited Test Ban Treaty (LTBT) was concluded on 5 August 1963. The expectations for international peace were turned on the 18th UN General Assembly of the next month. Kennedy intended to have refereed to the ratification of LTBT by U.S. Congress, but it was behind schedule. Accordingly, the proposal of the U.S.-Soviet joint lunar program came up as a subject of his speech. ${ }^{36)}$

Two Special Assistants for the President, Schlesinger and Bundy, made preparations for Kennedy's speech on the joint lunar program for the two reasons. First, the proposal would be appropriate to the UN General Assembly because it would create a peaceful framework in the Cold War. Second, such criticisms of Project Apollo as the "moondoggle" or the "science fiction stunt" were increasing year by year. The U.S.-Soviet space cooperation would lighten the burden of NASA and DOD in view of budget and organization. But, compared with the announcement of Project Apollo in May 1961, Kennedy and space advisors had no time to build the consensus within the government, Congress, and communities of space specialists.

On 20 September 1963, Kennedy proposed the U.S.-Soviet joint lunar program in the following speech before the UN General Assembly:

"Finally, in a field where the United States and the Soviet Union have a special capacity - in the field of space - there is room for new cooperation, for further joint efforts in the regulation and exploration of space. I include among these possibilities a joint expedition to the moon. Space offers no problems of sovereignty.... Surely we should explore whether the scientists and astronauts of our two countries - indeed of all the world - cannot work together in the conquest of space, sending some day in this decade to the moon not the representatives of a single nation, but the representatives of all of our countries."37)

This proposal brought surprise and confusion to the U.S. domestic society. On 17 September, three days before the proposal, Robert Gilruth, Director of NASA Manned Spacecraft Center, made a statement that the U.S.-Soviet joint lunar program would be difficult technically. The argument became heated in Congress. The supporters of Project Apollo lost the main purpose of beating the Soviet Union in the moon race. Democratic Representatives Albert Thomas and Olin E. Teague sent letters of protest to the President. Kennedy replied that "This great national effort [Project Apollo] and this steadily stated readiness to cooperate with others are not in conflict. They are mutually supporting elements of a single policy." ${ }^{\text {"38) }}$ This 
showed the basic stance of the Kennedy administration in space policy, but couldn't persuade the Apollo supporters.

On the other hand, the opponents of Project Apollo got the suitable chance to stop it. Through the efforts of Republican Representative Thomas M. Pelly, the restriction to prohibit cooperation on a lunar program with any other country without the consent of Congress was included in the NASA appropriation for the next three years. ${ }^{39)}$

Outside the United States, while European countries were relatively favorable to Kennedy's proposal, the Soviet Union assumed an ambiguous attitude toward it. But on 26 October 1963, Khrushchev stated at his press conference that "We are not at present planning flight by cosmonauts to the moon.... We do not want to compete with the sending of people to the moon without careful preparation.",40) This statement plunged Project Apollo into a crisis. U.S. Congress started to examine the slowdown of Project Apollo and review the whole U.S. space programs. Wiesner sent to Kennedy the memorandum titled "The US Proposal for a Joint US-USSR Lunar Program” that:

"I believe that Premier Khrushchev's statement of October 26 that the USSR does not plan to land a man on the moon gives us a unique opportunity to follow through on your UN proposal for a joint US-USSR program.... Specifically, I would propose a joint program in which the USSR provides unmanned exploratory and logistic support for the U.S. Apollo manned landing.... The proposal now not only offers a program which truly enhances the manned lunar exploration effort while leaving the Apollo program intact, but also one which ought to be acceptable to the USSR.... If the proposal is accepted we will have established a practical basis for cooperative program. If it is rejected we will have demonstrated our desire for peaceful cooperation and the sincerity of our original proposal."41)

Accepting Wiesner's proposal, Kennedy ordered NASA to prepare a specific plan along the line on 12 November. ${ }^{42)}$ But Kennedy fell to an assassin's bullet in Dallas, Texas on 22 November 1963. The news of his assassination was broadcasted live on TV to Japan by the U.S. communications satellite Relay 1. None other than Kennedy had been doing his best to realize the international network by communications satellites as early as possible.

If Kennedy had been not assassinated, Khrushchev might have accepted Kennedy's specific proposal and the U.S.-Soviet joint moon landing would have 
been realized somehow or other. It was reported that Khrushchev was never particularly interested in competing with Apollo. ${ }^{43}$ ) However, the Soviet Union began its own human lunar landing program only in August 1964, and Khrushchev was dismissed from Chairman's post in October of the same year. Eventually, the United States advanced Project Apollo by competing with the Soviet Union and succeeded in the first human moon landing by the spacecraft Apollo 11 on 20 July 1969.

\section{Conclusion}

The Kennedy administration chose Project Apollo as a crucial national policy that would bear part of the U.S. foreign policy in the Cold War, and advanced it on some occasions to win space competition with the Soviet Union, on others to realize space cooperation with the Soviet Union.

John F. Kennedy won the 1960 presidential election by taking a confrontational stance toward Khrushchev's Sputnik diplomacy. However, the Kennedy administration formulated the space policy for international cooperation in the first months of his administration in order to relieve the East-West tensions, especially in the third world. But in April 1961, the Kennedy administration suffered the two shocks, the "Gagarin shock" and the "Bay of Pigs shock." These fiascos in U.S. foreign policy made the Kennedy administration decide swiftly on Project Apollo in May 1961.

This decision and Kennedy's remarks on U.S.-Soviet space race have convinced us that the purpose of Project Apollo was to win space competition with the Soviet Union. However, even right before the announcement of Project Apollo, the Kennedy administration also tried to realize some U.S.-Soviet space cooperation including human lunar exploration. In the Vienna summit of June 1961, Kennedy proposed U.S.-Soviet joint lunar exploration for fear that Project Apollo should have a bad influence on U.S.-Soviet relations. After the UN resolution for international space cooperation of December 1961, the Kennedy administration started negotiations with the Soviet Union about space science cooperation with the Glenn's flight of February 1962 as an opportunity, while the administration was advancing Project Apollo.

The Cuban missile crisis of October 1962 made the Kennedy administration recognize the importance of both international cooperation and competition through space policy. While Kennedy made up his mind to proceed firmly with Project Apollo to compete with the Soviet Union, he continued the negotiations with the Soviet Union about space science cooperation. 
Because of the cooperative atmosphere right after the conclusion of LTBT and the increasing criticism toward the huge cost of Project Apollo, Kennedy proposed U.S.-Soviet space cooperation through Project Apollo itself, not only in space science, in the UN General Assembly of September 1963. Although the credibility and feasibility of Kennedy's proposal came into question, the Kennedy administration had devoted effort to the realization of U.S.-Soviet joint lunar landing until the assassination of Kennedy. Therefore, if the Kennedy administration had continued during the 1960s, the U.S.-Soviet joint lunar program might have developed in some way.

Thus, the Kennedy administration kept advancing Project Apollo by laying emphasis on competition or cooperation in accordance with the change of U.S.Soviet relations. This shows that the purpose of Project Apollo was not only to compete or cooperate with the Soviet Union in space activities. What did the Kennedy administration aim at through Project Apollo? As the previous studies have clarified, the administration tried to display the national power and ideas, or values, of the United States, and regain both the international status of the United States and the domestic status of the Kennedy administration. This purpose could be accomplished not only by winning the victory in space competition but also by demonstrating the leadership in space cooperation.

However, if the display of the U.S. power and ideas had been the only purpose of Project Apollo, why had the Kennedy administration prepared for U.S.-Soviet space cooperation concretely and repeatedly through the term of the Kennedy administration?

The concept of the foreign policy of the Kennedy administration was to first contain the expansion of the Communism bloc by the maintenance of the U.S. great military strength, negotiate with the Eastern leaders in quest of the common interests, and finally ease international tensions by accumulating the practical agreements between the East and the West. Also in space activities, the Kennedy administration tried to improve the U.S. space science and technology power, and Kennedy negotiated directly with Khrushchev on space cooperation. In short, the Kennedy administration strived to relax the tensions in the Cold War through its space policy including Project Apollo. The realization of U.S.-Soviet space cooperation would contribute to the easing of international tensions. Even if the full-scale space race to the moon kicked off, it would be rather desirable than military conflicts in Europe or the third world.

Therefore, it should be concluded that not only the display of U.S. power and ideas but also the relaxation of the tensions in the Cold War was the purpose of 
Project Apollo that was advanced by means of both competition and cooperation with the Soviet Union. Though it was in 1969 when the United States realized the first lunar landing through Project Apollo, the space policy of the Kennedy administration, with Project Apollo as the central program, restored gradually the U.S. international status, symbolized the relatively good relations between the United States and the Soviet Union, and contributed to the opening of the peaceful coexistence in the 1960 s, especially after the Cuban missile crisis, with other foreign policies of the administration.

\section{Notes}

1) W. D. Kay, "John F. Kennedy and the Two Faces of the U.S. Space Program, 1961-1963," Presidential Studies Quarterly, Volume 28, Number 3, Summer 1998, Stephen J. Garber, "Multiple Means to an End: A Reexamination of President Kennedy's Decision to Go to the Moon," Quest: The History of Spaceflight Quarterly, Volume 7, Number 2, Summer 1999, John M. Logsdon, “The Development of International Space Cooperation,” in John M. Logsdon, et al. eds., Exploring the Unknown: Selected Documents in the History of the U.S. Civil Space Program, Volume II: External Relationships (Washington, DC: NASA SP-4407, 1996), pp. 1-15, and Hirotaka Watanabe, Review Article "Timeless Decision: John M. Logsdon, The Decision to Go to the Moon: Project Apollo and the National Interest (Cambridge, MA: MIT Press, 1970)," Astropolitics, Volume 1, Number 3, Winter 2003.

2) For more details of the missile gap and the space gap, David Callahan and Fred I. Greenstein, "The Reluctant Racer: Eisenhower and U.S. Space Policy," in Roger D. Launius and Howard E. McCurdy eds., Spaceflight and the Myth of Presidential Leadership (Urbana and Chicago: University of Illinois Press, 1997), pp. 15-50, and Walter A. McDougall, ...the Heavens and the Earth: A Political History of the Space Age (New York: Basic Books, 1985).

3) Senator Kennedy's Remarks in the Senate, 14 August 1958, in Susan Miller, et al. eds., "Statements of John F. Kennedy on Space Exploration 1952-1963," July 1964, History Division, Office of External Relations, NASA.

4) John F. Kennedy, "If the Soviets Control Space, They Can Control Earth," Missiles and Rockets, 10 October 1960, pp. 12-13.

5) "Report to the President-Elect of the Ad Hoc Committee on Space," 10 January 1961, in John M. Logsdon, et al. eds., Exploring the Unknown: Selected Documents in the History of the U.S. Civil Space Program, Volume I: Organizing for Exploration (Washington, DC: NASA SP-4407, 1995), pp. 416-423.

6) Logsdon, The Decision to Go to the Moon, pp. 71-75.

7) “An Interview with John F. Kennedy," Bulletin of the Atomic Scientists, November 1960, p. 347.

8) "Inaugural Address of President John F. Kennedy," 20 January 1961, and "Annual Message to the Congress on the States of the Union," 30 January 1961, Public Papers of the Presidents of the United States, John F. Kennedy, 1961 (hereafter PPP, JFK, 1961), pp. 2 and 26-27.

9) Document 5, "Telegram From President Kennedy to Chairman Khrushchev," 13 February 
1961, and Document 6, "Message From Chairman Khrushchev to President Kennedy," 15 February 1961, in U.S. Department of State, Foreign Relations of the Unites States, 19611963, Volume VI, Kennedy-Khrushchev Exchanges (hereafter FRUS, 1961-1963, Volume $V I$ ). Available at $<\mathrm{http}: / /$ www.state.gov/r/pa/ho/frus/kennedyjf/>.

10) Document 386, "Memorandum from the President's Special Assistant for Science and Technology (Wiesner) to President Kennedy,” 20 February 1961, in FRUS, 1961-1963, Volume XXV, Organization of Foreign Policy; Information Policy; United Nations; Scientific Matters and the John F. Kennedy Library (hereafter, JFKL).

11) Logsdon, The Decision to Go to the Moon, pp. 85-100.

12) This chapter owes a great deal to Logsdon, The Decision to Go to the Moon, and Michael R. Beschloss, "Kennedy and the Decision to Go to the Moon", in Launius and McCurdy, Spaceflight and the Myth of Presidential Leadership, pp. 51-67.

13) Logsdon, The Decision to Go to the Moon, pp. 111-112.

14) Ibid.

15) Ibid.

16) Logsdon, The Decision to Go to the Moon, p. 112-121.

17) James E. Webb, NASA Administrator, and Robert S. McNamara, Secretary of Defense, to the Vice President, 8 May 1961 with attached: "Recommendations for Our National Space Program: Changes, Policies, Goals" in Logsdon, Exploring the Unknown, Volume I, pp. 439452.

18) Logsdon, The Decision to Go to the Moon, p. 126-127.

19) For more details of the preparatory process of the U.S.-Soviet summit meeting, Michael R. Beschloss, The Crisis Years: Kennedy and Khrushchev 1960-1963 (New York: HarperCollins Publishers, 1991), pp. 150-181.

20) Memorandum from Jerome B. Wiesner to John F. Kennedy, 16 May 1961, JFKL.

21) Aleksandr Fursenko and Timothy Naftali, One Hell of a Gamble: Khrushchev, Castro, and Kennedy, 1958-1964 (New York: W. W. Norton and Company, 1997), pp. 120-124.

22) John F. Kennedy, Excerpts from "Urgent National Needs," Speech to a Joint Session of Congress, 25 May 1961 in Logsdon, Exploring the Unknown, Volume I, pp. 453-454.

23) Document 84, "Memorandum of Conversation," Vienna, 3 June 1961, and Document 88, "Memorandum of Conversation," Vienna, 4 June 1961, FRUS, 1961-1963, Volume V, Soviet Union.

24) "Address in New York City Before the General Assembly of the United Nations," 25 September 1961, PPP, JFK, 1961, pp. 622-623.

25) Dodd L. Harvey and Linda C. Ciccoritti, U.S.-Soviet Cooperation in Space (Miami: University of Miami, 1974), pp. 82-86.

26) Document 35, "Letter From Chairman Khrushchev to President Kennedy," Moscow, 21 February 1962, FRUS, 1961-1963, Volume VI.

27) Document 36, "Telegram From the Department of State to the Embassy in the Soviet Union," Washington, 21 February 1962, FRUS, 1961-1963, Volume VI.

28) Harvey and Ciccoritti, U.S.-Soviet Cooperation in Space, pp. 92-105.

29) "Address at Rice University in Houston on the Nation's Space Effort," 12 September 1962, PPP, JFK, 1962, pp. 668-671.

30) For more details of the influence of the Cuba crisis on the military space programs, Derek W. Elliott, "Space: The Final Frontier of the New Frontier," in Mark J. White, ed., Kennedy: The New Frontier Revisited (New York: New York University Press, 1998), pp. 207-210. 
31) "Transcript of Presidential Meeting in the Cabinet Room of the White House, Topic: Supplemental appropriations for the National Aeronautics and Space Administration (NASA)," 21 November 1962, pp. 14-20. Available at <http://history.nasa.gov/JFKWebbconv/pages/transcript.pdf $>$.

32) Ibid.

33) Document 370, "Memorandum From the Administrator of the National Aeronautics and Space Administration (Webb) to the Chairman of the National Aeronautics and Space Council (Johnson)," 13 March 1962, Document 371, "Letter From Vice President Johnson to President Kennedy," 23 March 1962, and Document 372, "National Security Action Memorandum No. 144," 11 April 1962, FRUS, 1961-1963, Volume XXV.

34) Harvey and Ciccoritti, U.S.-Soviet Cooperation in Space, pp. 112-119.

35) “The President's News Conference of July 17, 1963," PPP, JFK, 1963, pp. 567-568.

36) Arthur M. Schelesinger, Jr., A Thousand Days: John F. Kennedy in the White House (New York: Houghton Mifflin Company, 2002), pp. 918-923, and Harvey and Ciccoritti, U.S.Soviet Cooperation in Space, pp. 120-123.

37) "Address Before the 18th General Assembly of the United Nations," 20 September 1963. PPP, JFK, 1963, pp. 693-698.

38) Letter form John F. Kennedy to Albert Thomas, 23 September 1963, JFKL.

39) Congressional Record, 10 October 1963, p. 19260, and 19 November 1963, p. 22357, quoted in Kay, John F. Kennedy and the Two Faces of the U.S. Space Program, 1961-63.

40) Izvestiya, 26 October 1963, quoted in Harvey and Ciccoritti, U.S.-Soviet Cooperation in Space, p. 124.

41) Document 408, Memorandum From the President's Special Assistant for Science and Technology (Wiesner) to the President, "The US Proposal for a Joint US-USSR Lunar Program," Washington, 29 October 1963, FRUS, 1961-1963, Volume XXV and JFKL.

42) National Security Action Memorandum No. 271, "Cooperation with the USSR on Outer Space Matters," 12 November 1963, with attached: Charles E. Johnson, Memorandum for Mr. Bundy, 16 December 1963, in Logsdon, Exploring the Unknown, Volume II, pp. 166167.

43) Asif A. Siddiqi, Sputnik and the Soviet Space Challenge (Gainesville, FL: University Press of Florida, 2003), p. 408. 
